\title{
The Promoting Force of Technology for Service Innovation in High-Tech Industries
}

\author{
Silvia Gliem, Janny Klabuhn, and Nadine Litwin
}

\author{
" (The advance of technology is based on making it fit in") \\ so that you don't really even notice it, so it's part of \\ everyday life.
}

\author{
Bill Gates \\ Former CEO and Chairman of Microsoft
}

\begin{abstract}
This article focuses on the interaction between the development of technology and service innovation. It goes "back to the basics" by analyzing the first theoretical contributions to the service innovation literature from the late 1980s. These contributions were heavily technologically oriented: they aimed at bringing the results of technological innovation to the realm of services. More specifically, we focus on the model of "reverse innovation cycle" on one hand, and on the first innovation-specific categorization of services on the other. The latter introduced the division into supplier-dominated, production-intensive/scaleintensive, and science-based services. Our purpose is to examine in which ways these theoretical approaches could promote our understanding about the new phenomena of technology-service interaction in innovation. In the second part of the article, we apply these approaches in five case studies that originate from different service industries and that differ in size and technologies. The findings of the analysis demonstrate that the applicability of the approaches to the case studies depends on several factors including the kind of technology involved in the innovation activities, the stage of development of this technology, and the type of service.
\end{abstract}

\section{Introduction}

The field of service innovation has been acknowledged, amongst others, as an emerging field of research within service science, and it is considered to be autonomous from traditional innovation research conducted in the manufacturing industry (Hipp \& Grupp, 2005; Miles, 2010; Toivonen \& Tuominen, 2009). Nonetheless, the quantity and variety of contributions to the field of service innovation in comparison to traditional innovation research lag behind (Wang et al., 2010). Advances in understanding of service innovation would enable researchers and firms to design more appropriate and target-oriented service innovation processes (Rubalcaba et al., 2010). Vargo and Lusch (2004) went further by proposing a new perspective on service science in general. They argue that concepts of innovation research should not evolve from manufacturing indus- tries. Instead, they emphasize the wide-ranging applicability of a service-centered perspective. For both a traditional and a service-centered perspective, there is no doubt that technology is one of the promoting forces that drive service innovation (Kandampully, 2002).

In this article, we depict the promoting force of technology towards service innovation in high-tech industries. Therefore, through this research, we ask: in what ways are service innovations driven by technology?

In answering these questions, the remainder of the article is structured as follows. First, we present two widely adopted and influential models of service innovation: i) the reverse innovation cycle model of Barras (1986a, $1986 \mathrm{~b}$ ) and ii) the typology of service innovation of Miozzo and Soete (2001). Next, we review literature that complements these two models. Then, for the purpose 


\title{
The Promoting Force of Technology for Service Innovation in High-Tech Industries
}

\author{
Silvia Gliem, Janny Klabuhn, and Nadine Litwin
}

of evaluation, we map five case studies originating from the high-tech industry to the two models of service innovation. Finally, we discuss the managerial implications.

\section{Barras' Reverse Innovation Cycle}

Barras' model of the "reverse innovation cycle" has been generally regarded as the first actual theory on service innovation (Gallouj, 1998; Toivonen \& Tuominen, 2009). Even though it is highly technologically biased, it has continuously aroused interest among those service researchers who have sought a strong linkage from service innovation to the general innovation theories. It is based on the "dynamic model of process and product innovation" by Utterback and Abernathy (1975), which shows the relationship between the forthcoming products of a firm from one product lifecycle stage to another and the adaption of a firms' innovative behaviour. The further a product proceeds in its lifecycle, the more likely it is that firms' focus on innovation activities shifts from product to process innovation. For service industries, Barras (1986a) predicts a reverse trajectory for this cycle, which is divided into three stages:

1. Firms adopt new technologies originating from a product innovation process and prove their spectrum of applicability. Mainly, their application results in incremental process innovations to increase efficiency and decrease costs.

2. Uncertainty concerning the adopted technology is eliminated. As a result, internal processes related to the application of the adopted technology are to be improved. Technology is still used for process innovations; however, in comparison to the first stage, the amount of incremental innovations declined, whereas radical process innovations aiming at quality improvement accumulate.

3. Product innovations are developed on the basis of the technology adopted in the first stage. If the development of product innovations is not done by firms themselves, it will be outsourced.

The reverse innovation cycle model of Barras was reviewed by several researchers (Gallouj, 1998; Tether \& Howells, 2007; Uchupalanan, 2000) who raised four issues with the model, as described below.

First, the focus on technology as a single factor liable to influence service innovation is criticized (Gallouj, 1998). Other factors, such as experiences and know- ledge accumulated during former innovation processes (Uchupalanan, 2000), were not taken into consideration. However, Barras includes these factors as drivers or restraints of the technology adoption process but not as influencing factors on service innovations (Barras, 1986a, 1990). Furthermore, by focusing on technology, Barras expels service innovations that do not contain technology, such as franchise systems.

Second, using Utterback and Abernathy's dynamic model of process and product innovation as a foundation, Barras adopted the differentiation between incremental and radical process innovation, and product innovation, which is considered problematic within the research community (Gallouj \& Savona, 2009; Salter \& Tether, 2014; Uchupalanan, 2000). Barras (1986a) addressed this problem and determined product innovations in services as "so different in nature and mode of delivery from more traditional forms of services that they can meaningfully be described as new service products." However, Barras only offers indications for determining whether a service innovation is a process or a product innovation (Gallouj, 1998). More precisely, Ettlie, Bridges, and O'Keefe (1984) state that "the strategy-structure causal sequence for radical innovation is markedly different from the strategy-structure sequence for incremental innovation." In other words, the extent to which an innovation makes organizational changes necessary, for example by the inclusion of customer learning, can be used as an indicator for the determination of the innovation type. This assertion is supported by Perks, Gruber, and Bo (2012), who characterize radical service innovations as powerful enough to cause fundamental changes in the structure, processes, and environment of an organization.

Third, focusing on information and communication technologies (ICT) as well as limiting the analysis to financial, business, and local government services creates doubts about the universal validity of the model (Tether \& Howells, 2007).

Fourth, the reverse innovation cycle cannot be observed ex ante. Only if a service firm adopted a technology and went through all stages, can it be concluded (ex post) that the reverse innovation cycle was undergone. In addition, Barras (1990) himself acknowledged that the pace of technology adoption will vary between service industries, which makes analysis difficult. Further, the substitution of one technology by another and the outsourcing of research activities linked to the adopted technology will interrupt or stop an industry from undergoing the reverse innovation cycle (Gallouj, 


\title{
The Promoting Force of Technology for Service Innovation in High-Tech Industries
}

\author{
Silvia Gliem, Janny Klabuhn, and Nadine Litwin
}

1998). These assumptions are supported by Uchupalanan (2000) who found that the Barras' model is only one of many possible innovation trajectories.

Service innovations developed by firms outside the service sector are not encompassed by Barras' model. For these particular cases, Cusumano, Kahl and Suarez (2006) developed a model that builds upon Utterback and Abernathy's model by including a fourth stage, which displays the shift from process to service innovation. The role of technology for service innovation is not determined in this model. It can, but must not have an influence on service innovation because, apart from technology, service innovation can originate out of accumulated knowledge, for example, about the behaviour of customers.

The review of innovation cycle models showed that the influence of technology is manifold: technology can be seen as a requirement for developing service innovations. This requirement applies, for example, to firms in the manufacturing industry that offer maintenance or repair services for their products. Likewise, technology is a starting point for the initiation of service innovation processes.

\section{Miozzo's and Soete's Typology of Service Innovation}

Miozzo and Soete $(1989,2001)$ developed the first typology for innovation in service firms focusing on the influence of ICT. Their work is based on the taxonomy by Pavitt $(1984,1991)$, who analyzed innovations over three decades but did not assign services an appropriate role in innovation (de Jong \& Marsili, 2006; Gallouj \& Savona, 2009). Miozzo and Soete's typology consists of three types. The first type comprises firms of small size, including science-based firms and specialized suppliers. Software industry and business services are allocated to this type. Next, there is the supplier-dominated type, which is represented by public and social services, as well as services close to home. Finally, there is the scale-intensive type, which is divided into two subtypes: physical networks and information networks. Logistics and wholesale belong to the scale-intensive type using physical networks. Financial, insurance and communicational services represent the scale intensive type using information networks. The authors emphasize the interrelations between the manufacturing and service industries. Services using information networks influence the development of technologies by signaling future demands to manufacturing industries, especially in terms of technologies that improve their networks in use. Furthermore, technology does not have to originate in manufacturing industries; for example, firms belonging to the science-based type and specialized suppliers can be developers of technology.

The typology of Miozzo and Soete $(1989,2001)$ was empirically validated by Evangelista (2000). His results show slight differences in comparison to the theoretically derived typology of Miozzo and Soete. The supplierdominated type converted into a technology user consisting of logistics, waste management, retail sale, and tourism. Evangelista states that the allocation of logistics as scale-intensive, physical-networks-based type is also reasonable. Advertisement, banking, and insurance are considered to be interactive and IT-based instead of scale-intensive information network based. For these particular service industries, innovations neither originate from the adoption of technology nor from firms' own development. Instead, they are created on the foundation of obtained and accumulated knowledge. Science-based and specialized suppliers representing research and development and consulting services stayed the same.

De Jong and Marsili (2006) developed a corresponding taxonomy for small and medium-sized firms. They identified four types, but due to the objects analyzed, they introduced a resource-intensive type in place of a scale-intensive type. Firms belonging to the resourceintensive type often emphasize budget expenditure and effort for the development of innovation.

The taxonomy of Vence and Trigo (2009) divides the service sector into three types. There are industries of low innovation intensity, presented by wholesale, for example. Further, there are technology-intensive service industries of medium innovation intensity, such as financial services. Knowledge-intensive service industries, such as consultancy, are considered to be highly innovation intensive.

Taxonomies and typologies demonstrate the attempt to deal with the complexity and variety of services. However, the typology of Miozzo and Soete lacks the inclusion of non-technological innovations or at least the consideration of factors that are interrelated with technology and therefore potentially influential (Tether et al., 2001; Tether \& Tajar, 2008).

Although the reverse innovation cycle model by Barras and the typology of service innovation by Miozzo and Soete were published more than ten years ago, our review demonstrated that they are frequently discussed 


\title{
The Promoting Force of Technology for Service Innovation in High-Tech Industries
}

\author{
Silvia Gliem, Janny Klabuhn, and Nadine Litwin
}

models in the service innovation literature and provide the basis for many newer works. Both Barras as well as Miozzo and Soete focused their analysis on ICT. By this approach, they narrowed the validity of their models to a certain group of technologies and stage of development of these technologies. Applying these models to up-to-date ICT and other technologies, such as robotics, will expand the validity of the models, uncover potential for modification, and provide a revised starting point for the future development of new models of service innovation.

\section{Research Methodology}

A multi-case study method was chosen because it allows us to include and combine heterogeneous sources of information (Baxter \& Jack, 2008), such as interviews and data from annual reports of companies. Further, processes that continue over time and might have had different starting points, such as development processes, can be examined in detail with this approach. Interconnections between processes also can be considered (Yin, 2003). The study of multiple cases should provide an insight into the diverse shapes and characteristics of one examined phenomenon and permit us to deduct robust conclusions (Eisenhardt, 1989; Yin, 2003). In this article, five cases are analyzed. The sources of information for making up the cases vary between personal interviews (Case 1 and Case 2), literature research (Case 3 and Case 4), and data from a university research project (Case 5). The technologies examined in the cases had different starting points of development and are interwoven. For instance, ICT started developing in the middle of the 20th century and operated as an enabler for the development of other technologies, such as robotics.

We analyzed the cases in three steps. First, we want to prove whether service firms are technology adopters when developing service innovations or technology developers. By this, we will clarify that technology actually is a force of promoting nature to service innovation. Second, the cases will be mapped to Barras' reverse innovation cycle model. Therefore, we need to differentiate between incremental and radical process innovation, and product innovation. Third, the applicability of the typology of Miozzo and Soete for service innovations and later modifications is to be evaluated focusing on the basis of the information obtained from the first and second steps of analysis. The focus is set on the congruency of the results of service innovation anticipated by the typologies and taxonomies and the actual results in the different case studies.

\section{Case selection}

The main selection criterion for the case studies was the application of a technology to or within a service process that was not used in this combination before. In other words, all service innovations analyzed within a case would not have been developed without technology or a combination of technologies. Further selection criteria included the context (i.e., business-to-business, business-to-consumer, or both), the size of firm, and the type of service industry. A selection of cases that differ from each other in the above-mentioned criteria was considered to be valuable according to the advantages of the multi-case method. The case selection covers a broad range of service firms and a wide variety of services.

The technologies considered as influential within the five cases range from robotics (two cases), automation technology (one case), information and communication technology (one case), and additive manufacturing (one case). All case studies are set in different high-tech industries, produce different services, and differ in size. Two of the firms are small (1-49 employees), one of the firms is medium-sized (50-249 employees), and two of the firms are large (>250 employees) (cf. Audretsch et al., 2009). Three cases are set in a business-to-business-context. These three cases also can be found in a businessto-consumer-context, but the firms presented in these cases offer their service exclusively to business customers. Two firms presented in the case studies provide their services to business and private customers. Table 1 provides an overview of the five cases, which are described in greater detail in the following section.

\section{Case Descriptions}

Case 1: Automation technology in car rental services Customers of car rental services are often time-sensitive business travelers. At locations where many people wish to rent a car, for example, at the airport, delays can occur. With the help of automation technology, a worldwide car rental service developed an automatic car rental machine, which facilitated the car rental process in various ways. Customers can go directly to the car park where the machines are set up. Via touchscreen they initiate the rental process. The car keys can be taken out of the automatic car rental machine by pulling out a solid metallic cylinder. Customers returning the car go through a similar process.

\section{Case 2: ICT in postal services}

To most of us, email services are an essential part of our private and working lives. At the same time, customers 


\section{The Promoting Force of Technology for Service Innovation in High-Tech Industries}

Silvia Gliem, Janny Klabuhn, and Nadine Litwin

Table 1. Overview of the five case studies

\begin{tabular}{|c|c|c|c|c|c|}
\hline & Case 1 & Case 2 & Case 3 & Case 4 & Case 5 \\
\hline Description & $\begin{array}{l}\text { Automation } \\
\text { technology in car } \\
\text { rental services }\end{array}$ & $\begin{array}{l}\text { ICT in postal } \\
\text { services }\end{array}$ & $\begin{array}{l}\text { Additive } \\
\text { manufacturing in } \\
\text { dentistry }\end{array}$ & $\begin{array}{l}\text { Robotics in } \\
\text { logistics }\end{array}$ & $\begin{array}{l}\text { Robotics in } \\
\text { industrial laundry } \\
\text { services }\end{array}$ \\
\hline Firm size & Large & Small & Small & Large & Medium \\
\hline Operating context & B2B \& B2C & $\mathrm{B} 2 \mathrm{~B}$ & $\mathrm{~B} 2 \mathrm{C}$ & $\mathrm{B} 2 \mathrm{~B} \& \mathrm{~B} 2 \mathrm{C}$ & $\mathrm{B} 2 \mathrm{C}$ \\
\hline Innovation & $\begin{array}{l}\text { Automatic car } \\
\text { rental machine } \\
\text { (rental kiosk) for } \\
\text { independent car } \\
\text { rentals and returns }\end{array}$ & $\begin{array}{l}\text { Email service for } \\
\text { secure sending } \\
\text { and receiving of } \\
\text { legally binding } \\
\text { emails and } \\
\text { electronic } \\
\text { documents }\end{array}$ & $\begin{array}{l}\text { Stereolithography } \\
\text { technology for } \\
\text { manufacturing } \\
\text { dental splints }\end{array}$ & $\begin{array}{l}\text { Unloading robot } \\
\text { for incoming } \\
\text { freight containers }\end{array}$ & $\begin{array}{l}\text { Service robot } \\
\text { substituting } \\
\text { manual } \\
\text { operations }\end{array}$ \\
\hline Type of innovation & Process & Product & Process & Process & Process \\
\hline $\begin{array}{l}\text { Motive for } \\
\text { innovation }\end{array}$ & $\begin{array}{l}\text { - Increase in } \\
\text { competitiveness } \\
\text { - Satisfaction of } \\
\text { customer needs }\end{array}$ & $\begin{array}{l}\text { - Expansion of } \\
\text { the range of } \\
\text { products } \\
\text { - Adaptation to } \\
\text { market } \\
\text { conditions }\end{array}$ & $\begin{array}{l}\text { - Satisfaction of } \\
\text { customer needs } \\
\text { - Process } \\
\text { optimization }\end{array}$ & $\begin{array}{l}\text { - Reduction of } \\
\text { load on } \\
\text { employees } \\
\text { - Process } \\
\text { optimization }\end{array}$ & $\begin{array}{l}\text { - Reduction of } \\
\text { risk of health } \\
\text { and safety in } \\
\text { the workplace } \\
\text { - Process } \\
\text { optimization }\end{array}$ \\
\hline $\begin{array}{l}\text { Development } \\
\text { of innovation }\end{array}$ & - Internal & $\begin{array}{l}\text { - Internal } \\
\text { - Frame } \\
\text { specified by } \\
\text { government }\end{array}$ & $\begin{array}{l}\text { - In collaboration } \\
\text { with specialized } \\
\text { suppliers }\end{array}$ & $\begin{array}{l}\text { - Internal } \\
\text { - In collaboration } \\
\text { with research } \\
\text { institutes }\end{array}$ & $\begin{array}{l}\text { - In collaboration } \\
\text { with specialized } \\
\text { suppliers and } \\
\text { research } \\
\text { institutes }\end{array}$ \\
\hline Type of technology & $\begin{array}{l}\text { - Automation } \\
\text { technology } \\
\text { - ICT }\end{array}$ & • ICT & $\begin{array}{l}\text { - Additive } \\
\text { manufacturing } \\
\text { - ICT }\end{array}$ & $\begin{array}{l}\text { - Robotics } \\
\text { - ICT }\end{array}$ & $\begin{array}{l}\text { - Robotics } \\
\text { - ICT }\end{array}$ \\
\hline $\begin{array}{l}\text { Sources of } \\
\text { technology }\end{array}$ & $\begin{array}{l}\text { Specialized } \\
\text { supplier }\end{array}$ & - Own research & $\begin{array}{l}\text { - Specialized } \\
\text { supplier }\end{array}$ & $\begin{array}{l}\text { - Research } \\
\text { institute } \\
\text { - Specialized } \\
\text { supplier }\end{array}$ & $\begin{array}{l}\text { - Research } \\
\text { institute } \\
\text { - Specialized } \\
\text { supplier }\end{array}$ \\
\hline
\end{tabular}

of email services are not aware of their privacy protection. Therefore, governments determined that some documents, such as tax assessment notices or articles of association, cannot be sent via email. Instead, they must be in written form. The German government decided that, in some cases, the obligatory written form can be substituted by a qualified electronic signature. The service firm presented in the case provides this special email service for firms. The email service contains several modules. Apart from a basic module consisting of the mailbox, additional modules can be obtained for end-to-end encryption, qualified electronic signature, and storage.

\section{Case 3: Additive manufacturing in dentistry}

People with bruxism or teeth grinding suffer from headaches, dental abrasion, and jaw pain (Carlsson et al., 2003). Therefore, the production of custom-fitting, indi- 


\title{
The Promoting Force of Technology for Service Innovation in High-Tech Industries
}

\author{
Silvia Gliem, Janny Klabuhn, and Nadine Litwin
}

vidual dental splints is gaining more importance in dentistry (Hoffmann, 2003). The traditional approach to fabricating dental splints is complex and time consuming; it begins with taking a dental impression of the client's teeth, which is then used to create a plaster cast, upon which the dental split is constructed (Polzin \& Seitz, 2012). Additive manufacturing, or in this specific context stereolithography, is capable of facilitating this process significantly and further improving quality and fitting accuracy (Chengtao et al., 2006; Salmi, 2013; Van Noort, 2012). It constitutes a means of production that is crucial for the improvement of the whole service process that aims at the provision of patients with dental splints. Instead of taking a dental impression, additive fabrication begins with a computed axial tomography (CAT) scan of the client's teeth, which is used to create a 3D model of the dental splint, which is then printed using a stereolithography machine. Compared to the traditional approach, which takes from 4 to 10 days, the entire process of additive fabrication takes between 10 and 20 hours. The combination of additive manufacturing and ICT, presented by the CAT scan, permits to shorten the whole service process of producing a customized dental splint in terms of production time and feedback loops necessary to guarantee the proper fit of the splint.

\section{Case 4: Robotics in logistics}

In the packaging centre of a transport and logistics service provider, packages are sorted before being delivered to customers. Employees work in shifts 24 hours per day and 7 days per week to deliver packages as fast as possible. Cargo of incoming delivery trucks has to be unloaded by hand and put on a conveyor belt to be delivered to another delivery truck (Scholz, 2006; Vahrenkamp, 2005). Two issues threaten the health and safety of employees in their workplace (Echelmeyer et al., 2009; Schmidt \& Rohde, 2010): i) large and heavy packages, such as automotive parts, have to be unloaded by hand and ii) stacks of packages can become unstable and fall onto employees. To confront these problems, a worldwide operating provider of transport and logistics services developed an unloading robot in collaboration with public research institutes. Once in position, a scanning system enables the unloading robot to recognize the exact location of the packages inside the truck and tells the robot where to grab them. The unloading robot is capable of unloading between 450 and 600 packages per hour (Echelmeyer et al., 2009).

\section{Case 5: Robotics in industrial laundry services}

Industrial laundries are well known for their automation systems (Vickery, 1972). Furthermore, radio-frequency identification (RFID) technology has lately been widely implemented (Cangialosi et al., 2007). However, due to high levels of complexity and multiplicity, manual work is still required. Employees within industrial laundries servicing hospitals have to deal with heavy loads of laundry. Furthermore, they are exposed to highly contaminated and possibly infectious laundry items, especially when opening laundry bags by hand. A group of German researchers developed a service robot that partly substitutes manual work processes in industrial laundry services. For instance, the robot automatically opens laundry bags, reads RFID tags that are sewed in to the laundry items, and carries them to the conveyor belt. Heavy and wet laundry items can easily be processed, even during peaks of demand.

\section{Case Analysis}

In every case, technology was significant for service innovation. In fact, in four cases (1, 3, 4, and 5), a combination of two or more technologies formed the foundation for service innovation. ICT formed part of every one of these combinations. Although only five cases were considered and only one service innovation is based mainly on ICT (Case 2), the predominance of these technologies for service innovations is well represented in our study and coincides with the results of previous research (Higón, 2011; Jiménez-Zarco et al., 2011; Scupola \& Tuunainen, 2011).

With regard to our research question, which concerned the ways in which service innovations are driven by technology, our cases indicate a variety of approaches. In Case 3, technology was adopted from the manufacturing industry, in particular from sectors dealing with mechanical engineering and frequently using prototypes, or other customized, prefabricated parts. In Case 1 and Case 2, technology incorporated in the service innovation was developed by the firms' own research and development departments. Two firms collaborated with public research institutions (Case 4 and Case 5). However, basic know-how of these technologies was adopted in each of the five cases. Robotics know-how (Case 4 and Case 5) was probably adopted from branches of industry using assembly devices, whereas know-how of automation technology (Case 1) was obtained from plant engineering and construction.

When applying the Barras model to our cases, we used the indicators included in the model, which led to debatable results. Our analysis will demonstrate that the indicators offered by Barras' model in some cases are not sufficient for determining whether an innovation is 


\title{
The Promoting Force of Technology for Service Innovation in High-Tech Industries
}

\author{
Silvia Gliem, Janny Klabuhn, and Nadine Litwin
}

of an incremental or radical nature. According to Barras, the car rental services case can be characterized as a radical process innovation that significantly improves the quality of the service process, for example, by reducing waiting periods. At the same time, this innovation can be considered an incremental process innovation. It does not result in substantial changes for the car rental service firm nor does it require the acquisition of knowledge by the customer given that automation technology has surrounded our everyday life for more than two decades.

In the second case, service innovation was developed on the basis of information technologies that are considered to be highly diffused within the service industry (Djellal et al., 2013; Gago \& Rubalcaba, 2007). By creating an email service with security options that facilitate sending and receiving emails with legal validity - in other words, improving the quality of the service - a radical process innovation was developed.

Again, this case demonstrates that Barras does not offer clear-cut criteria for assigning an innovation to one of the phases of his reverse innovation cycle. For this specific case, one can also argue that an email service with a qualified signature is not an innovation at all. Instead, it constitutes an example of adoption and implementation of earlier innovations.

The fabrication of dental splints via additive manufacturing (Case 3) represents an incremental process innovation in dentistry services. Improvements of quality for customers and providers, for example, by improved fitting accuracy, are achieved. Considering the past, this case reveals that the introduction of the CAT scanning technology might have been a radical process in- novation to dentistry services as the handling of this new technology - for example, the scanning facility itself and the data processing software - have had to be learned by employees.

For laundry services as well as logistics, robotics is integrated into the overall operating systems. The determination of the process innovation type for these cases is highly dependent on the judge's point of view. For customers of an industrial laundry service, a laundry processing robot remains invisible. Improvements in quality will be marginal, whereas improvements in terms of efficiency will be noticed. Referring to the continuous threatening of employees' health, a laundry processing robot would stand for a significant improvement of health and safety in the workplace. For customers, logistics might improve on behalf of the delivery speed. Dependent on the extent to which delivery speed has increased, customers will perceive the service innovation as an incremental or radical process innovation. Although, one has to keep in mind, that the operation of an unloading robot remains invisible for customers. For employees, an unloading robot has visible advantages, including improved health and safety in the workplace. For both cases, the improvement can be perceived as an incremental or radical process innovation. The criterion of customer learning cannot be applied to both of the cases because, for customers, the innovations remain invisible.

The assignment of the cases to Miozzo and Soete's typology is summarized in Table 2. The typology covers all service industries presented in the cases. However, Case 5 is problematic because industrial laundry services are not considered services that are "close to home". Instead, they are assigned as public or social

Table 2. Assignment of cases to the typology of Miozzo and Soete (2001)

\begin{tabular}{lllll}
\hline & Case 1 & Case 2 & Case 3 & Case 4 \\
\hline Description & $\begin{array}{l}\text { Automation } \\
\text { technology in car } \\
\text { rental services }\end{array}$ & $\begin{array}{l}\text { ICT in postal } \\
\text { services }\end{array}$ & $\begin{array}{l}\text { Additive } \\
\text { manufacturing in } \\
\text { dentistry }\end{array}$ & $\begin{array}{l}\text { Robotics in logistics } \\
\text { Robotics in industrial } \\
\text { laundry services }\end{array}$ \\
\hline $\begin{array}{l}\text { Supplier-dominated } \\
\text { OR }\end{array}$ & $\begin{array}{l}\text { Scale-intensive with } \\
\text { physical networks }\end{array}$ & $\begin{array}{l}\text { Knowledge } \\
\text { specialized supplier }\end{array}$ & $\begin{array}{l}\text { Supplier- } \\
\text { dominated }\end{array}$ & $\begin{array}{l}\text { Scale-intensive } \\
\text { with physical } \\
\text { networks }\end{array}$ \\
\hline $\begin{array}{l}\text { Innovation } \\
\text { types }\end{array}$ & Process optimization & $\begin{array}{l}\text { Innovative } \\
\text { products }\end{array}$ & $\begin{array}{l}\text { Process } \\
\text { optimization }\end{array}$ & $\begin{array}{l}\text { Process } \\
\text { optimization }\end{array}$ \\
\hline
\end{tabular}




\title{
The Promoting Force of Technology for Service Innovation in High-Tech Industries
}

\author{
Silvia Gliem, Janny Klabuhn, and Nadine Litwin
}

services. Both Case 4 and Case 5 used robotics and developed their service innovation in collaboration with public research institutions. Such a collaboration as a source of technology does not appear in the typology. However, in both cases, specialized suppliers originating in the manufacturing industry were granted a license to do further fabrication and maintenance.

Regarding the purpose of introducing a technology, the case data reflects Miozzo and Soete's expectations, except with Case 3, which does not fit. According to Miozzo and Soete's typology, Case 3 belongs to the knowledge-intensive type or specialized supplier.

\section{Conclusion and Managerial Implications}

Our case analysis demonstrated that technology has significant influence on the development of service innovations. Its characterization as a promoting force therefore is justified.

The reverse innovation cycle model of Barras, although not capable of displaying the dynamics of service innovation processes, demonstrates that service innovation and technology are interconnected. Further, the model indicates that the type of technology-service interaction results in different types of innovation. However, the indicators offered in the model of Barras are not sufficient.

A more precise approach to reflect the interconnections between service innovation and technology is the typology of Miozzo and Soete. It addresses the variety of the service sector and reveals technology-service interactions that are typical for certain service industries. Therefore, it enables managers to analyze and compare past technology-service interactions with present developments and conditions.

As the frontier between service and manufacturing firms blurs, future research has to deal with several fundamental questions referring to a service-dominant logic or the differentiation of process and product innovations and their characterization as incremental or radical. In this regard, the definition and measurement of intensity of innovation has to be reconsidered. At the same time, the measurement of productivity and quality of pre and post conditions of innovation has to be brought forward.

\section{About the Authors}

Silvia Gliem is a PhD student in Business Administration at Brandenburg University of Technology Cottbus-Senftenberg, Germany. She obtained her Bachelor's degree in International Business Administration from European University Viadrina in Frankfurt (Oder), Germany, and she holds a Master's degree in Business Administration from Brandenburg University of Technology in Cottbus, Germany. Her research interests focus on service productivity and service innovation research. She recently joined a research project that focuses on the improvement of health and safety in the workplace by means of a service robot. In the context of this project, she depicts the influence of physical surroundings and safety in the workplace on employees.

Janny Klabuhn is a $\mathrm{PhD}$ student in Industrial Engineering at Brandenburg University of Technology Cottbus-Senftenberg, Germany. She holds a diploma in Industrial Engineering from Brandenburg University of Technology in Cottbus, Germany. Her fields of research include human resource management, innovation management, and automation technology. She is part of a research project that aims at the development of a service robot to improve health and safety in the workplace. Within this project, she analyzes the transformational processes in human resources originating from the increasing application of automation technology in certain service industries.

Nadine Litwin is a PhD student in Business Administration at Brandenburg University of Technology Cottbus-Senftenberg, Germany. She received her diploma in Industrial Engineering from the Brandenburg University of Technology in Cottbus, Germany. Her research encompasses rapid prototyping, production processes, and disruptive innovation. In particular, she focuses on the diffusion of technologies that endanger firm's traditional competitive strategies, and the potential reorganization needs for manufacturing industries. 


\section{The Promoting Force of Technology for Service Innovation in High-Tech Industries}

Silvia Gliem, Janny Klabuhn, and Nadine Litwin

\section{References}

Audretsch, D., Horst, R. van der, Kwaak, T., \& Thurik, R. 2009. First Section of the Annual Report on EU Small and Medium-sized Enterprises. Zoetermeer: EIM Business \& Policy Research.

Barras, R. 1986a. Towards a Theory of Innovation in Services. Research Policy, 15(4): 161-173.

http://dx.doi.org/10.1016/0048-7333(86)90012-0

Barras, R. 1986b. New Technology and the New Services - Towards an Innovation Strategy for Europe. Futures, 18(6): 748-772. http://dx.doi.org/10.1016/0016-3287(86)90125-4

Barras, R. 1990. Interactive Innovation in Financial and Business Services: The Vanguard of the Service Revolution. Research Policy, 19(3): 215-237.

http://dx.doi.org/10.1016/0048-7333(90)90037-7

Baxter, P., \& Jack, S. 2008. Qualitative Case Study Methodology: Study Design and Implementation for Novice Researchers. The Qualitative Report, 13(4): 544-559.

Cangialosi, A., Monaly, J. E., \& Yang, S. C. 2007. Leveraging RFID in Hospitals: Patient Life Cycle and Mobility Perspectives. IEEE Communications Magazine (Applications \& Practice), 45(9): 18-23. http://dx.doi.org/10.1109/MCOM.2007.4342874

Carlsson, G. E., Egemark, E., \& Magnusson, T. 2003. Predictors of Bruxism, Other Oral Parafunctions, and Tooth Wear over a 20-Year Follow-up Period. Journal of Orofacial Pain, 17(1): 50-57.

Chengtao, W., Shilei, Z., Xiaojun, C., \& Yanping, L. 2006. A Novel Method in the Design and Fabrication of Dental Splints Based on 3D Simulation and Rapid Prototyping Technology. The International Journal of Advanced Manufacturing Technology, 28(9-19): 919-922.

http://dx.doi.org/10.1007/s00170-004-2197-1

Cusumano, M., Kahl, S., \& Suarez, F. F. 2006. Product, Process, and Service: A New Industry Lifecycle Model (Paper 228). Cambridge Massachusetts: MIT Sloan School of Management.

de Jong, J. P. J., \& Marsili, O. 2006. The Fruit Flies of Innovations: A Taxonomy of Innovative Small Firms. Research Policy, 35(2): 213229.

http://dx.doi.org/10.1016/j.respol.2005.09.007

Djellal, F., Gallouj, F., \& Miles, I. 2013. Two Decades of Research on Innovation on Services: Which Place for Public Services? Structural Change and Economic Dynamics, 27(2013): 98-117. http://dx.doi.org/10.1016/j.strueco.2013.06.005

Echelmeyer, W., Pallasch, A.-K. ,\& Rohde, M. 2009. Die „Logistikfabrik der Zukunft“ - ein ganzheitliches Konzept. Industrie Management, 25(5): 13-17.

Eisenhardt, K. M. 1989. Building Theories from Case Study Research. Academy of Management Review, 14(4): 532-550. http://dx.doi.org/10.5465/AMR.1989.4308385

Ettlie, J. E., Bridges, W. P., \& O’Keefe, R. D. 1984. Organization Strategy and Structural Differences for Radical Versus Incremental Innovation. Management Science, 30(6): 682-695. http://dx.doi.org/10.1287/mnsc.30.6.682

Evangelista, R. 2000. Sectoral Patterns of Technological Change in Services. Economics of Innovation and New Technology, 9(3): 183221.

http://dx.doi.org/10.1080/10438590000000008
Gago, D., \& Rubalcaba, L. 2007. Innovation and ICT in Service Firms: Towards a Multidimensional Approach for Impact Assessment. Journal of Evolutionary Economics, 17(1): 25-44. http://dx.doi.org/10.1007/s00191-006-0030-8

Gallouj, F. 1998. Innovating in Reverse: Services and the Reverse Product Cycle. European Journal of Innovation Management, 1(3): 123-138. http://dx.doi.org/10.1108/14601069810230207

Gallouj, F., \& Savona, M. 2009. Innovation in Services: A Review of the Debate and a Research Agenda. Journal of Evolutionary Economics, 19(2): 149-172. http://dx.doi.org/10.1007/s00191-008-0126-4

Higón, D. 2011. The Impact of ICT on Innovation Activities: Evidence for UK SMEs. International Small Business Journal, 30(6): 684699 http://dx.doi.org/10.1177/0266242610374484

Hipp, C., \& Grupp, H. 2005. Innovation in the Service Sector: The Demand for Service-Specific Innovation Measurement Concepts and Typologies. Research Policy, 34(4): 517-535. http://dx.doi.org/10.1016/j.respol.2005.03.002

Hoffman, A. 2003. Die Aufbissschiene aus primosplint. QZ Quintessenz Zahntechnik, 29(5): 626-634.

Jiménez-Zarco, A. I., Martínez-Ruiz, M. P., \& Izquierdo-Yusta, A. 2011. Key Service Innovation Drivers in the Tourism Sector: Empirical Evidence and Managerial Implications. Service Business, 5(4): 339-360. http://dx.doi.org/10.1007/s11628-011-0118-6

Kandampully, J. 2002. Innovation as the Core Competency of a Service Organization: The Role of Technology, Knowledge and Networks. European Journal of Innovation Management, 5(1): 1826.

http://dx.doi.org/10.1108/14601060210415144

Miles, I. 2010. Service Innovation. In P. P. Maglio, C. Kieliszweski \& J. C. Spohrer (Eds.), Handbook of Service Science: 511-533. New York: Springer.

http://dx.doi.org/10.1007/978-1-4419-1628-0_22

Miozzo, M., \& Soete, L. 2001. Internationalization of Services: A Technological Perspective. Technological Forecasting and Social Change, 67(2-3): 159-185. http://dx.doi.org/10.1016/S0040-1625(00)00091-3

Pavitt, K. 1984. Sectoral Patterns of Technical Change: Towards a Taxonomy and a Theory. Research Policy, 13(6): 343-373. http://dx.doi.org/10.1016/0048-7333(84)90018-0

Pavitt, K. 1991. Key Characteristics of the Large Innovating Firm. British Journal of Management, 2(1): 41-50. http://dx.doi.org/10.1111/j.1467-8551.1991.tb00014.x

Perks, H., Gruber, T., \& Edvardsson, B. 2012. Co-Creation in Radical Service Innovation: A Systematic Analysis of Microlevel Processes. Journal of Product Innovation Management, 29(6): 935-951. http://dx.doi.org/10.1111/j.1540-5885.2012.00971.x

Polzin C., \& Seitz H. 2012. 3D-Druck von KunststoffMedizinprodukten. RTejournal, 2012(9): 1-7.

Rubalcaba, L., Gago, D., \& Gallego, J. 2010. On the Differences between Goods and Services Innovation. Journal of Innovation Economics, 5(1): 17-40. http://dx.doi.org/10.3917/jie.005.0017 


\section{The Promoting Force of Technology for Service Innovation in High-Tech Industries Silvia Gliem, Janny Klabuhn, and Nadine Litwin}

Salmi, M. 2013. Medical Applications of Additive Manufacturing in Surgery and Dental Care. Doctoral Dissertation: Aalto University.

Salter, A., \& Tether, B. S. 2014. Innovation in Services: An Overview. In K. Haynes \& I. Grugulis (Eds.), Managing Services: Challenges \& Innovation: 134-153. Oxford: Oxford University Press.

Schmidt, K. \& Rohde, M. 2010. Low Cost Automation in der Logistik. Zeitschrift für wirtschaftlichen Fabrikbetrieb, 105(1-2): 91-95.

Scholz, E. 2006. Enthüllungsgeschichte: Ein Roboter packt aus. Logistik \& Fördertechnik, 2006(12): 32-33.

Scupola, A., \& Tuunainen, V. 2011. Open Innovation and Role of ICT in Business-to-Business Services: Empirical Evidence from Facility Management Services. Sprouts: Working Papers on Information Systems, 11(58).

Tether, B. S., Hipp, C., \& Miles, I. 2001. Standardisation and Particularisation in Services: Evidence from Germany. Research Policy, 30(7): 1115-1138.

http://dx.doi.org/10.1016/S0048-7333(00)00133-5

Tether, B. S., \& Howells, J. 2007. Changing Understanding of Innovation on Services: From Technological Adoption to Complex Complementary Changes to Technologies, Skills and Organization (DTI Occasional Paper No. 9). DTI.

Tether, B. S., \& Tajar, A. 2008. The Organisational-Cooperation Mode of Innovation and its Prominence amongst European Service Firms. Research Policy, 37(4): 720-739. http://dx.doi.org/10.1016/j.respol.2008.01.005

Toivonen, M., \& Tuominen, T. 2009. Emergence of Innovation in Services. The Service Industries Journal, 29(7): 887-902. http://dx.doi.org/10.1080/02642060902749492
Uchupalanan, K. 2000. Competition and IT-Based Innovation in Banking Services. International Journal of Innovation Management, 4(4): 455-489. http://dx.doi.org/10.1142/S1363919600000238

Utterback, J. M., \& Abernathy, W. J. 1975. A Dynamic Model of Process and Product Innovation. The Omega, 3(6): 639-656. http://dx.doi.org/10.1016/0305-0483(75)90068-7

Vahrenkamp, R. 2005. Logistik - Management und Strategien (5th Ed.). Munich: Oldenbourg.

Van Noort, R. 2012. The Future of Dental Devices is Digital. Dental Materials, 28(1): 3-12. http://dx.doi.org/10.1016/j.dental.2011.10.014

Vargo, S. L., \& Lusch, R. F. 2004. Evolving to a New Dominant Logic for Marketing. The Journal of Marketing, 68(1): 1-17. http://dx.doi.org/10.1509/jmkg.68.1.1.24036

Vence, X., \& Trigo, A. 2009. Diversity of Innovation Patterns in Services. The Service Industries Journal, 29(2): 1635-1657. http://dx.doi.org/10.1080/02642060902793631

Vickery, M.L. 1972. New Technology in Laundry and Cleaning Services. Monthly Labor Review, 95(2): 54-59. http://www.jstor.org/stable/41838539

Wang, W., Hsu, H. Y. S., Yen, H. R., Chiu, H.-C., \& Wei, C.-P. 2010. Developing and Validating Service Innovation Readiness. PACIS 2010 Proceedings, 71.

Yin, R. K. 2003. Case Study Research - Design and Methods (3rd Ed.). Thousand Oaks: Sage. 